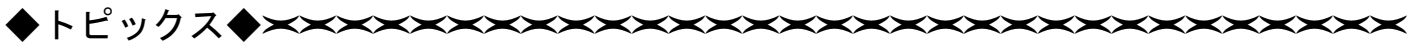

\title{
FDP-Dダイマー測定の現状と課題
}

香川和彦

Current topics of FDP D-dimer assays

Kazuhiko KAGAWA

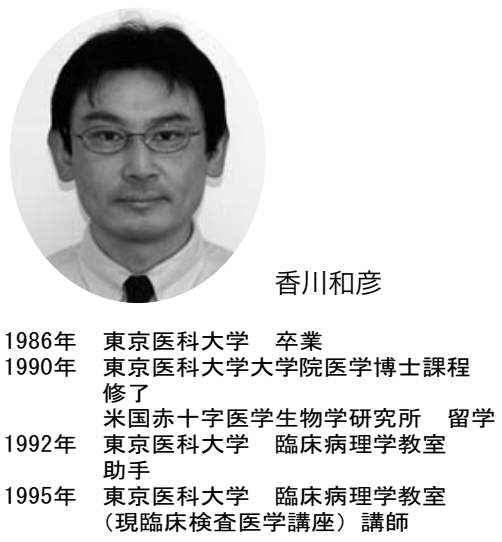

フィブリノゲン・フィブリン分解産物 (FDP) の D ダイマー分画を測定するキットが開発さ れて 20 年が経過し，その臨床的有用性が取り 上げられて久しい。本稿では, 臨床検査医学の 観点から，FDP-D ダイマー測定の現状と課題 についてあらためて整理してみたい.

\section{FDP-D ダイマー測定法の現状}

安定化 (架橋化) フィブリン分解産物 (XDP) を含むFDP 全体を捉える測定法（total FDP； tFDP または FDP-E) に対して，D ダイマー分 画を検出して 1 次・ 2 次線溶を鑑別しようとす る試みは, 古くはゲルろ過法や二次元免疫電気 泳動法などでおこなわれたが，臨床検査として の実用性を満たさなかった。 D ダイマー分画に 対するモノクロナル抗体の作成が進むと，1985 年頃から免疫学的原理による測定キットが次々 と開発されてきた。

現在, 国内で利用できる主な D ダイマー測 定キットを表 1 にまとめた. D ダイマーそのも のは分解産物であり生物学的活性がないので, モノクロナル抗体を用いた免疫学的原理で検出 される，大別すると，用手法による簡便な半定
量的ラテックス凝集法と，定量的なラテックス 免疫比濁法, 酵素免疫法 (EIA), 蛍光免疫法 （FIA）がある。また免疫クロマトグラフィ法を 利用したテストストリップによる迅速検査法も 開発されている.これはへパリン加全血検体を そのまま測定するので遠心分離が不要となり, POCT (point of care testing) として救急医療で の利用や，またドライケミストリー検査なので 災害時でも活用できる。

いずれの測定キットも，フィブリノゲンとは 交差反応をきたさない抗 D ダイマー・モノク ロナル抗体を用いるので，検体中にフィブリノ ゲンが存在していても理論的には反応しない. 従って検体としては血清と血漿の両者が利用で きることになる. tFDP と同時に測定すること が多いので, 従来の FDP 専用 (トロンビン・ レプチラーゼ・アプロチニン入り）採血管で血 清検体を共用することができる，また最近は血 漿 FDP (pFDP) 測定キットが普及してきたた め，この場合は $3.2 \%$ クン酸ナトリウム加血 漿検体で共用でき，他の多くの凝固線溶系検査 にもそのまま使用できる。院内に FDP 専用試 験管を常備する必要がなく，また採血量を極力 少なくしたい場合にも便利である。

東京医科大学臨床検査医学講座〔干 160-0023 新宿区西新宿 6-7-1〕

Department of Laboratory Medicine, Tokyo Medical University [6-7-1 Nishishinjuku, Shinjuku-ku, Tokyo 160-0023, Japan]

Tel: 03-3342-6111 (内線 5087) Fax: 03-3340-5448 e-mail: kazz@tokyo-med.ac.jp 
表 1 国内で利用できる主な D ダイマー測定試薬

\begin{tabular}{|c|c|c|c|}
\hline 測定原理 & 試薬名 & 参考基準值 & 製造 \\
\hline \multirow{4}{*}{ ラテックス凝集法 } & イアトロDD/Eテスト & $<1.0 \mu \mathrm{g} / \mathrm{m} l$ & 三菱化学ヤトロン (MKI) \\
\hline & フィブリノスチコン & $<0.5 \mu \mathrm{g} / \mathrm{m} l$ & 日本ビオメリュー(BMJ) \\
\hline & Dダイマー測定用試薬「RD」 & $<0.5 \mu \mathrm{g} / \mathrm{m} l$ & ロシュ・ダイアグノスティックス \\
\hline & ラピディアD-dimer II & $<200 \mathrm{ng} / \mathrm{ml}$ & AGEN \\
\hline \multirow{12}{*}{ ラテックス免疫比濁法 } & エルピアエースD-Dダイマー II & $<1.0 \mu \mathrm{g} / \mathrm{ml}$ & 三菱化学ヤトロン (MKI) \\
\hline & イアトロエースD-Dダイマー II & $<1.0 \mu \mathrm{g} / \mathrm{ml}$ & 三菱化学ヤトロン (MKI) \\
\hline & オートダイマーテスト & $\leqq 0.2 \mu \mathrm{g} / \mathrm{m} l$ & 日本ビオメリュー (BMJ) \\
\hline & MDA用イアトロエースD-Dダイマー II & $\leqq 1.0 \mu \mathrm{g} / \mathrm{m} l$ & 日本ビオメリュー(BMJ) \\
\hline & STA用ライアテストDダイマー & $\leqq 0.4 \mu \mathrm{g} / \mathrm{m} l$ & ロシュ・ダイアグノスティックス \\
\hline & コバス試薬Dダイマー & $\leqq 1.0 \mu \mathrm{g} / \mathrm{ml}$ & ロシュ・ダイアグノスティックス \\
\hline & ティナクアントDダイマー & $\leqq 0.5 \mu \mathrm{g} / \mathrm{m} l$ & ロシュ・ダイアグノスティックス \\
\hline & リアスオート・Dダイマー ネオ & $<1.0 \mu \mathrm{g} / \mathrm{ml}$ & シスメックス \\
\hline & エルピアD-Dダイマー & $<1.0 \mu \mathrm{g} / \mathrm{ml}$ & シスメックス \\
\hline & ナノピアDダイマー & $\leqq 1.0 \mu \mathrm{g} / \mathrm{m} l$ & 第一化学薬品 \\
\hline & LATECLE Dダイマー試薬 & $\leqq 1.0 \mu \mathrm{g} / \mathrm{m} l$ & カイノス \\
\hline & ランピアラテックスDダイマー & $\leqq 1.0 \mu \mathrm{g} / \mathrm{ml}$ & 極東製薬 \\
\hline \multirow{2}{*}{ 酵素免疫法 } & アセラクロムDダイマー & $\leqq 400 \mathrm{ng} / \mathrm{ml}$ & ロシュ・ダイアグノスティックス \\
\hline & $\mathrm{D}$ ダイマーテスト「コクサイ」F F & $\leqq 0.5 \mu \mathrm{g} / \mathrm{m} l$ & シスメックス \\
\hline \multirow{2}{*}{ 蛍光免疫法 } & バイダスアッセイキットDダイマー2 & $<500 \mathrm{ng} / \mathrm{m} l$ & 日本ビオメリュー(BMJ) \\
\hline & エバテストDダイマー & $<1.0 \mu \mathrm{g} / \mathrm{m} l$ & 日水製薬 \\
\hline 免疫クロマト法 & カーディアック試薬Dダイマー & $<0.5 \mu \mathrm{g} / \mathrm{ml}$ & ロシュ・ダイアグノスティックス \\
\hline
\end{tabular}

D ダイマーは，血栓の存在を示唆する代表的 マーカーとして, 深部静脈血栓症 (DVT) や肺 塞栓症（PE）の除外診断，播種性血管内凝固症 （DIC）の診断基準（表 2) などに導入され臨床 的に活用されている. 旧厚生省 DIC 診断基準 （1992 年）では血清 FDP をスコアリング項目と し, 補助的検査成績・所見のひとつとしてD ダイマーが高值であることが含まれているが, どの程度を高值とするかは明言されていない1). また国際血栓止血学会／標準化委員会 (ISTH/ SSC) の提案した DIC 診断基準 (2001年) で は, D ダイマーはFDPや可溶性フィブリン (SF) と同格に扱われスコアリングに関与して いるが，具体的な数值設定はされていない2). いずれの診断基準においても，Dダイマー值の 解釈は主観的な判断に任されていることにな る.このように曖昧な表現にせざるを得ない背
景には，D ダイマーの特性に起因する問題点が あることを理解しなければならない.

\section{FDP-D ダイマー測定の特性と問題点}

D ダイマーを含めた FDP 測定の特性と問題 点を図 1 にまとめた，FDP 全般の特性は，生 物学的活性を有しない多様性 (heterogeneity) に富んだ抗原の集合であることと，線溶が立進 すると出現する分子マーカーであることであ る。従って測定上の問題点としては，絶対的な 標準物質（primary standard）が存在せず，凝固 因子活性の定量検査のように正常検体の単純な 希釈列を用いて検量線を作成できないことがあ げられる。各測定キットには定量化の根拠とな る calibrator（D ダイマー標準品）が指定されて いるが，ある測定法の calibrator が他の測定法 


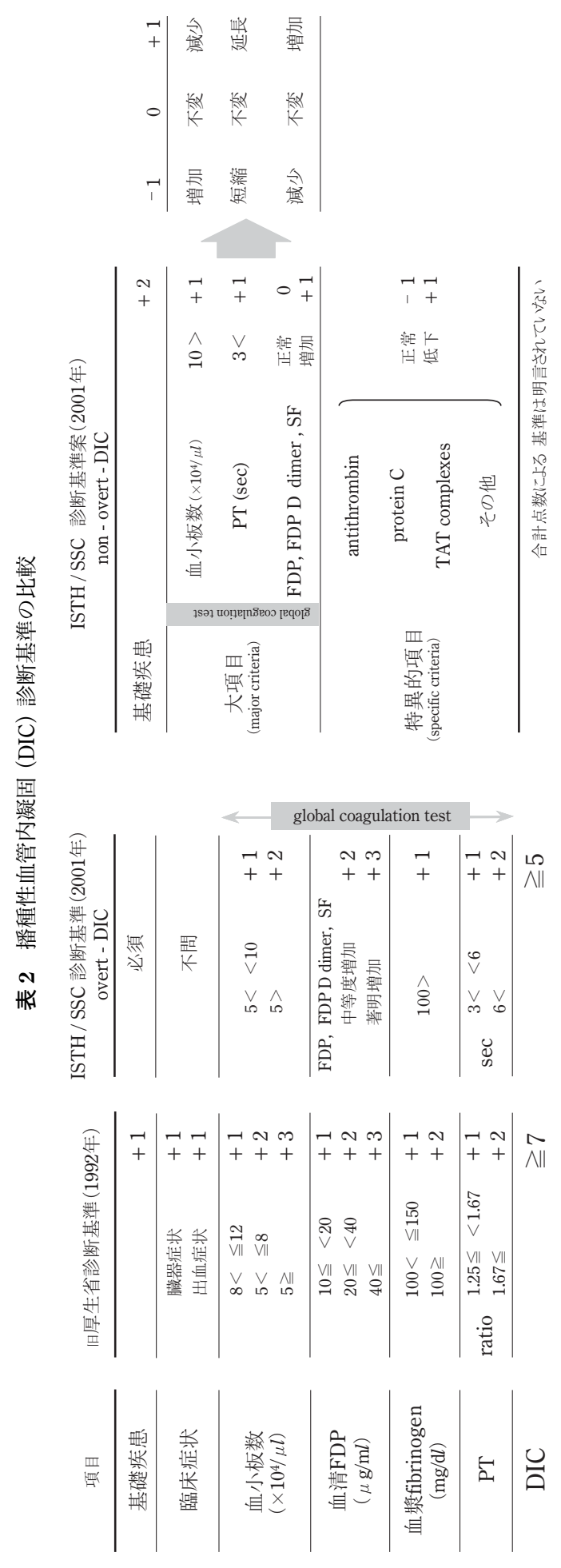

では非常に低值になったり，全く測定できない ことがある゙．これはモノクロナル抗体の特異 性や反応性が，測定キットごとに異なるためで ある。また calibrator が同じ $\mu \mathrm{g} / \mathrm{m} l$ 単位を使用 していても, 純化 D ダイマー分画による DD units と，フィブリン塊の材料となった血漿フ イブリノゲン量で表現する FEU (fibrinogen equivalent units）があり，理論的には $1 \mathrm{FEU} は$ 2DDunitsに相当することも確認しておく必要 がある ${ }^{3)}$.さらに測定原理や装置の差異や，同 一キットでも血清検体と血漿検体による差異の 問題などがある。これらの複雑な要因が D ダ イマーの測定法間差を発生させ，さらに標準化 を困難にしていることになる．試薬間差を是正 する何らかの標準化の方法論が確立されない と, 測定法や病態ごとに異なるカットオフ值を, どのように調整して診断基準や診断指針などに 盛り込むか, という課題も解決されない.

\section{FDP-D ダイマーの測定法間差の} 問題と解決への方向性

\section{— standardization から harmonization $へ$ 一}

D ダイマー測定法の個別の検討では，それぞ れが血栓症の診断に有用であることを報告して いるが，次第に測定法間差の問題が指摘されは じめた ${ }^{4)-6)}$. Meijer らは血栓止血関連検査の外 部精度管理組織（ECAT Foundation）の結果か ら，測定法間でのばらつきが著しいことを指摘 している7).この問題は ISTH/SSC でも 1990 年代終わり頃から議論されるようになり，標準 化の必要性が議論されるようになってきた。し かし，フィブリン塊をプラスミンで分解させて 得た純化 D ダイマーを 1 次標準試料として標 準化 (standardization) する試みは成功していな い ${ }^{8)}$. 2000 年からは独立して D ダイマー検討部 会が設置され，Dempfle らはいろいろなフィブ リン分解産物検体を多種類の測定キットを比較 する The Fibrin Assay Comparison Trial (FACT) ${ }^{9)}$ 


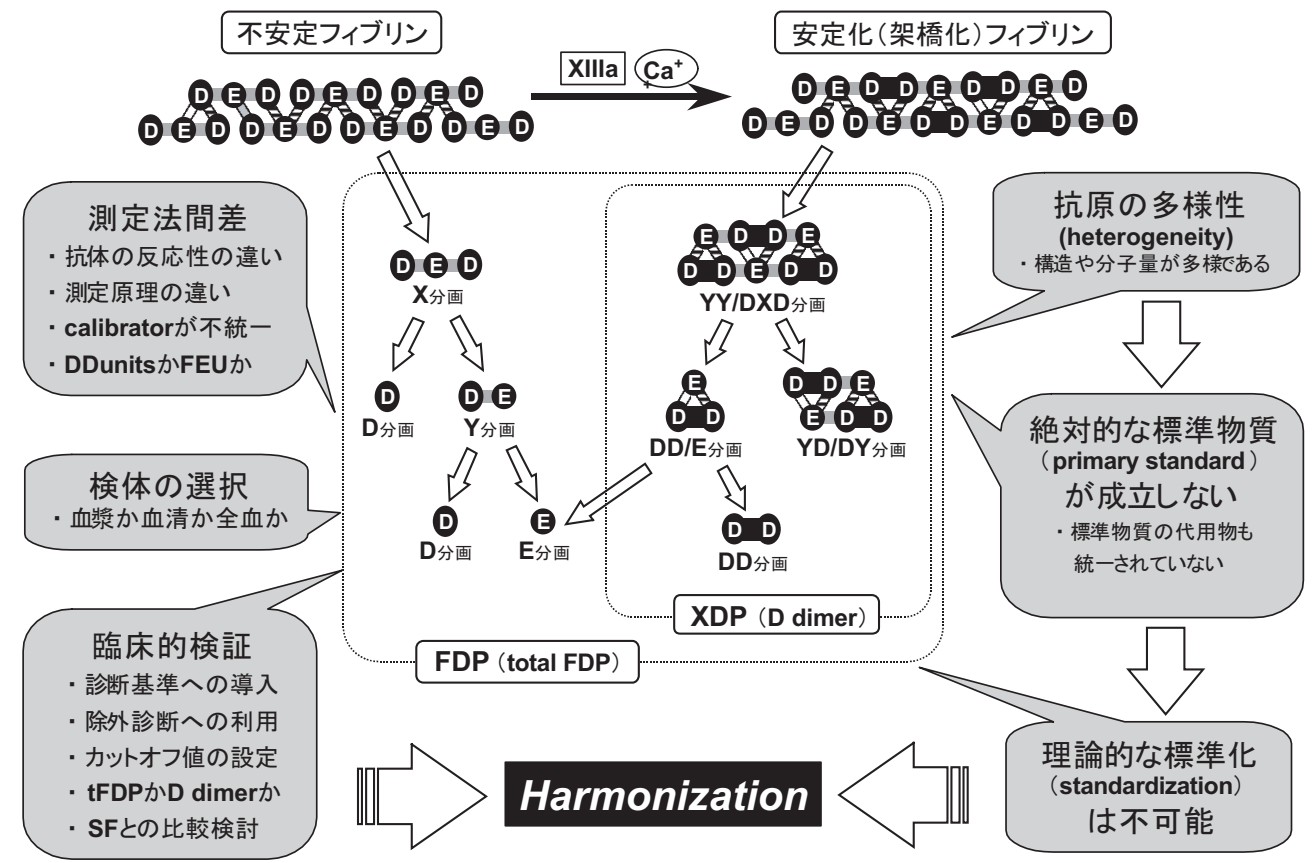

図 1 フィブリノゲン・フィブリン分解産物 (FDP) の特性と測定上の問題点

を継続して報告してきた。 日本の試薬メーカー も参加した FACT round 4 の成績が 2005 年に報 告され，高分子分解産物を含む各種病態の患者 プール血漿検体を測定して数学的に換算処理す れば，測定法間差は調整（harmonization）でき 得るとの方向性を結論付けている。また各測定 キットにおける DVT 除外診断のカットオフ值 設定のためにも, 凍結乾燥患者プール血漿によ る calibratorの確立が必要であると提言してい る.

本邦でも, 日本臨床検査医学会と日本検査血 液学会の標準化委員会・血栓止血検査小委員会 では, 国内試薬メーカーの参加と協力で, FDP および D ダイマーの試薬間差の是正に向けた 基礎的検討が始められている。この検討では ECAT や FACT と同様に患者検体を利用するが， おおよその濃度別に患者血清をプールして，8 階調の標準管理血清セットを作製している ${ }^{10)}$. 各管理血清の D ダイマーを各試薬で測定する が, 絶対值を確定できないので, 各試薬の 5 回
平均値の中央值を各管理血清のコンセンサス值 として暫定している. 暫定コンセンサス值と各 試薬の実測值を，直線回帰式で換算して試薬間 差を調整するという方法であり，いわゆる試薬 間の harmonization である（図 2) ${ }^{11)}$. 第 5 回日 本検査血液学会学術集会 (2004 年) における標 準化委員会中間報告では，高濃度領域の実測值 はばらつきが大きくなる傾向があるが，低濃度 領域では標準管理血清による harmonizationの 可能性が示唆されている. 特に基準值前後から 低濃度領域にかけて試薬間差が是正されること ができれば，各種病態におけるカットオフ值の 設定や，診断基準における重症度分類などに大 きく貢献できるものと考えられる.

もちろん臨床的検証によりデータを集積し て，この方法論の妥当性を評価する作業を繰り 返さなければならない。そして calibrator や管 理血清などの標準代用検体の QC (品質管理) をどのように行うか, また評価されるべきかと いう課題は, harmonizationの根幹に関わるも 


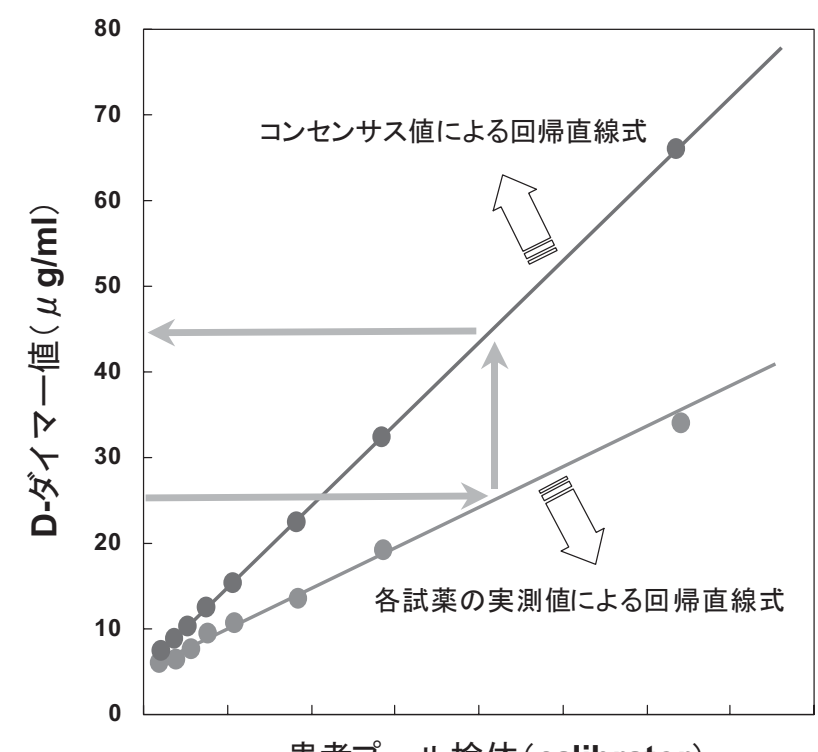

患者プール検体 (calibrator)

*文献11)を一部改変

図 2 Harmonization の理論 (実測值からコンセンサス值への変換)*

のだけに特に重要である.

\section{文献}

\section{FDP-D ダイマー測定の今後}

ISTH/SSC では，2006 年以降にキャリブレ ータによる harmonizationの成否が報告される であろう。本邦でも引き続き標準化委員会の検 討が行われ，また 2006 年度には，日本血栓止 血学会にもISTH/SSC に対応する標準化委員 会が設置されるので，日本臨床検査医学会や日 本検査血液学会との連携により, 基礎から臨床 まで包括的な検討が期待されるところである。

\section{おわりに}

多施設での比較研究などで D ダイマー值を解 釈する場合，この検査法の厳密な standardization は不可能であり，測定法間の harmonizationの 模索が始まったばかりであるということは，常 に認識しておく必要がある。
1）青木延雄，長谷川淳：DIC 診断基準の「診断のための補 助的検査成績, 所見」の項の改訂について. 厚生省特定 疾患血液凝固異常症調査研究班. 昭和 62 年度研究報告書, 1988, p37-41.

2) Taylor Jr FB, Toh CH, Hoots WK, Wada H, Levi M: Towards Definition, clinical and Laboratory Criteria, and a Scorind System for Disseminated Intravascular Coagulation on behalf of the Scientific Subcommittee on Disseminated Intravascular Coagulation(DIC) of the International Society of Thrombosis and Haemostasis(ISTH). Thromb Haemost 86 : 1327-1330, 2001.

3) Reber G, de Moerloose PH: D-dimer assays for the exclusion of venous thromboembolism. Semin Thromb Haemost 26 : 619-624, 2000.

4) Freyburger G, Trillaud H, Labrouche S, Gauthier P, Javorschi S, Bernard P, Grenier N: D-dimer strategy in thrombosis exclusion. A gold standard study in 100 patients suspected of deep venous thrombosis or pulmonary embolism:8 DD methods compared. Thromb Haemost $79: 32-37,1998$.

5) van der Graaf F, van den Borne H, van der Kolk M, de Wild PJ, Janssen GW, van Uum SH: Exclusion of deep venous thrombosis with D-dimer testing-comparison of 13 D-dimer nethods in 99 outpatients suspected of deep venous thrombosis using venography as reference standard. Thromb Haemost 83 : 191-198, 2000.

6) Schutgens RE, Haas FJ, Gerritsen WB, van der Horst F, Nieuwenhuizen HK, Biesma DH: The usefulness of five $\mathrm{D}$-dimer assays in the exclusion of deep venous thrombosis. J Thromb Haemost 1 : 976-981, 2003.

7) de Mant MP, Meijer P, Nieuwenhuizen W, Haverkate F, Kluft 
C: Performance of semiquantitative and quantitative D-dimer assays in the ECAT external quality assessment program. Semin Thromb Hemost 26(6) : 625-630, 2000.

8) Nieuwenhuizen W: A reference material for harmonization of D-dimer assays. Fibrinogen Subcommittee of the Scientific and Standardization Committee of the International Society of Thrombosis and Haemostasis.Thromb Haemost 77 : 1031-1033, 1997.

9) Dempfle CE, Zips S, Ergul H, Heene DL: Fibrin Assay Comparison Trial study group:The Fibrin Assay Comparison Trial(FACT): evaluation of 23 quantitative $\mathrm{D}$-dimer assays as basis for the development of D-dimer calibrators.Thromb Haemost 85(4): 671-678, 2001.

10) Fukutake K, Nakayama H, Nishiwaki K, Oyo Y, Baba Y, Tanabe H, Koshihara K, Kagawa K, Amano K: Standardization of assays for plasma fibrin-fibrinogen degradation products. J Thromb Haemost. 3(Suppl. 1): P0800, 2005

11) Meijer P, Kluft C: The harmonization of quantitative test results of different D-dimer methods. Semin Vasc Med 5 : 321-327, 2005. 